\title{
Kleine-Levin Syndrome: History and Brief Review
}

\author{
J.M.S. Pearce \\ Emeritus Consultant Neurologist, Department of Neurology, Hull Royal Infirmary, Hull, UK
}

\section{Key Words}

Kleine-Levin syndrome • Episodic hypersomnia • Compulsive eating $\cdot$ Sexual behaviour $\cdot$ Diencephalon . Hypothalamus

\section{Abstract \\ Episodic hypersomnia, compulsive excessive eating and erotic behaviour, with schizophrenic-like mental symptoms are the hallmarks of the rare Kleine-Levin syndrome. This paper traces the origins of its description back to the 18th century and the changing concepts of its complex organic- psychogenic aetiology. The eventual, spontaneous disap- pearance of the syndrome is unexplained.}

Copyright $\odot 2008$ S. Karger AG, Basel

Kleine-Levin syndrome is one of those rare disorders of function of the brain whose clinical characteristics are both fascinating and mystifying. It is characterized by periodic hypersomnia, compulsive excessive eating (megaphagia), and erotic behaviour. Macdonald Critchley elegantly described it as:

'A periodic disorder occurring chiefly in adolescent males, with schizophrenic-like mental symptoms, associated with diverse autonomic disorders, in nature organic but wholly mysterious' [1].

\section{History}

In 1925, Willi Kleine, a neurologist, collected from the clinic of Professor Kleist in Frankfurt a series of five patients with 'periodic sleepiness' of diverse aetiology [2]. Four years later, Max Levin, a psychiatrist from New York, writing on narcolepsy described a single atypical case of periodic somnolence combined with excessive appetite. In 1936, Levin republished this case [3], suggesting 'a syndrome of periodic somnolence and morbid hunger' and reported five other patients, including one of Kleine's.

Critchley first wrote about this disorder in 1942 [4]. In 1962 , he added to the literature 11 cases he had personally observed in the Royal Navy and provided its eponym [5]. He described as characteristic, irascibility, depersonalisation, vivid fantasies often with violent or sexual colouring, and odd behaviour. Arnulf et al. [6] compiled an exhaustive review of 186 cases published between 1962 and 2004.

Brierre de Boismont reported a possible case in 1862 [cited in 6], several decades prior to the 1916-1927 epidemic of encephalitis lethargica. A possible earlier instance is that reported by Edmé Chauvot de Beauchêne (1749-1824) [cited in 7] who described a 24-year-old woman whom he had examined during four attacks of hypersomnia, which lasted between $24 \mathrm{~h}$ and 8 days. He reported:

\section{KARGER \\ Fax +41 613061234 \\ E-Mail karger@karger.ch}

www.karger.com (c) 2008 S. Karger AG, Basel 0014-3022/08/0604-0212\$24.50/0

Accessible online at: www.karger.com/ene
J.M.S. Pearce

304 Beverley Road

Anlaby, East Yorks HU10 7BG (UK) 
'In her fourteenth year, she was overcome with a lethargic sleep which lasted several days; and it was so profound that she was believed dead. From that point forward, the affection of sleep recurred at irregular intervals; it usually lasted eight to ten days, continuing at times for fifteen; and upon one sole occasion, it persisted into the seventeenth day ... During the first four years of her disease, this poor girl had appetites as bizarre as they were dangerous, causing her to eat lime, plaster, soil, and vinegar. Thereafter, these appetites subsided, and she nourished herself indiscriminately with all sorts of aliment, excepting bread, for which she maintained an insuperable loathing till she was perfectly cured. This food always occasioned vomiting.'

Beauchêne does not mention megaphagia per se, nor sexual symptoms, but his descriptions of recurrent episodes of hypersomnia, accompanied by peculiar eating habits resemble Kleine-Levin syndrome. Beauchêne studied at and graduated from Montpellier, where one of his mentors was the well known F. Boissier de Sauvages.

Critchley [5] provided the essence of the syndrome in 1962:

'Thirty-three years ago a syndrome of "morbid hunger and periodic somnolence" was first extracted out of the amorphous and miscellaneous groups of cases of pathological sleep. Twenty years ago it first received the status of the "Kleine-Levin syndrome". Since then it has been possible to establish 4 other important clinical features which may be interpreted in either of two ways. Either, these features are integral and important aspects of the Kleine-Levin syndrome; or else, another syndrome exists allied to, but independent of, what is commonly termed the Kleine-Levin syndrome.

'These 4 hallmarks ... are: (1) sex incidence whereby males are preponderantly if not wholly affected; (2) onset in adolescence; (3) spontaneous eventual disappearance of the syndrome, and (4) the possibility that the megaphagia is in the nature of a compulsive eating, rather than a bulimia.'

Single case reports slowly accumulated. In 2005, Arnulf et al. [6], collated details of 186 patients from 139 articles. Most (68\%) were men, with a median age at onset of 15 years; the syndrome lasted 8 years, with 7 episodes lasting 10 days, recurring every 3.5 months (median values). Of many drugs tested, only lithium produced a modest reduction of relapses.

In 1980, Popper et al. [8] described a familial aggregation in a Hawaii-Caucasian kindred with at least 9 affected members. To date, few other familial cases have been described, but a report by Katz and Ropper [9] described an affected brother and sister.

No consistent or conclusive findings have been shown on MRI, EEG, or CSF examinations. Polysomnography during attacks may show a destructured pattern of sleep, with frequent awakenings from stage 2 sleep [10]. Hypoperfusion of the thalamus, and less constantly in fronto- temporal lobes, shown by single-photon emission computed tomography (SPECT) is seen during hypersomnic episodes.

\section{Aetiology}

Clinical and laboratory findings point to a periodic disturbance of function in the diencephalon, particularly the hypothalamus, probably involving medial temporal areas. Many authors $[1,11]$ conclude that the physiopathology is unclear. In their 1942 paper, Critchley and Hoffman [4] suggested an infectious or inflammatory aetiology and there are several reports of a mild infective illness preceding attacks in up to $50 \%$ of cases. A possible relation to narcolepsy has been suggested [3], but normal CSF hypocretin levels in one of the sibs (reported by Katz and Ropper [9]), who shared the HLA-DR2 and HLADQ1 antigens, argues against this conjecture. In 30 unrelated patients with Kleine-Levin syndrome, Dauvilliers et al. [12] found an increased frequency of the human leukocyte antigen $\mathrm{DQB1}^{*} 0201$ allele $(28.3$ vs. $12.5 \%$ in controls). One subject and his affected mother were DQB1 ${ }^{*} 0201$ homozygous. Viral infections were the most frequent precipitating factor $(70 \%)$ but, with slender supporting clinical data, Dauvilliers et al. suggested an autoimmune aetiology. Others have related the syndrome to affective disorders or to psychosis [13], though a primarily organic disorder seems more likely. The eventual, spontaneous disappearance of the syndrome is as mysterious as the mechanisms determining its periodicity, and should prompt future investigation.

\section{Treatment}

Management is mainly supportive with attention to skin, bowels, bladder and nutrition during phases of impaired consciousness and withdrawal. No adequately controlled trials have established any drug that will rapidly reverse the somnolent state, but of many drugs tried, only lithium appears to produce a modest reduction of relapses [6]. 


\section{References}

1 Critchley M: The syndrome of hypersomnia and periodical megaphagia in the adult male (Kleine-Levin): what is its natural course? (In French.) Rev Neurol (Paris) 1967;116: 647-650.

2 Kleine W: Periodische Schlafsucht. Monatsschr Psychiatrie Neurolog 1925;57:285-320.

3 Levin M: Periodic somnolence and morbid hunger: a new syndrome. Brain 1936;59: 494-504.

4 Critchley M, Hoffman H: The syndrome of periodic somnolence and morbid hunger (Kleine-Levin syndrome). BMJ 1942;1:137139.
5 Critchley M: Periodic Hypersomnia and megaphagia in adolescent males. Brain 1962; 85:627-656

6 Arnulf I, Zeitzer JM, File J, Farber N, Mignot E: Kleine-Levin syndrome: a systematic review of 186 cases in the literature. Brain 2005; $128: 2763-2776$.

7 Walusinski O: Observation of a nervous disease attended by disturbed sleep, at times lethargic and at times convulsive. Edmé Chauvot de Beauchêne (1786). J Neurol Neurosurg Psychiatry 2007;78:975-976.

8 Popper JS, Hsia YE, Rogers T, Yuen J: Familial hibernation (Kleine-Levin) syndrome (abstract). Am J Hum Genet 1980;32:123A.

$>9$ Katz JD, Ropper AH: Familial Kleine-Levin syndrome: two siblings with unusually long hypersomnic spells. Arch Neurol 2002;59: 1959-1961.
10 Gadoth N, Kesler A, Vainstein G, Peled R, Lavie P: Clinical and polysomnographic characteristics of 34 patients with KleineLevin syndrome. J Sleep Res 2001;10:337341

11 Garland H, Sumner D, Fourman P: The Kleine-Levin syndrome. Some further observations. Neurology 1965;15:1161-1167.

12 Dauvilliers Y, Mayer G, Lecendreux M, Neidhart E, Peraita-Adrados R, Sonka K, Billiard M, Tafti M: Kleine-Levin syndrome: an autoimmune hypothesis based on clinical and genetic analyses. Neurology 2002;59: 1739-1745.

13 Lemire I: Review of Kleine-Levin syndrome: toward an integrated approach. Can J Psychiatry 1993;38:277-284. 